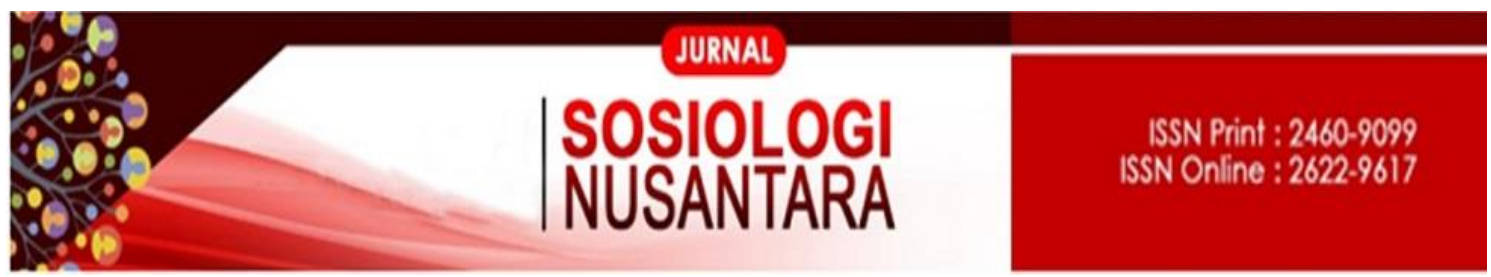

\title{
UPAYA MELESTARIKAN BUDAYA INDONESIA DI ERA GLOBALISASI
}

Effort To Preserve Inddonesian Culture In The Era Of Globalization

\author{
Hildigardis M. I. Nahak \\ nahakhildigardis@gmail.com
}

Fakultas Ilmu Sosial dan Ilmu Politik, Universitas Nusa Cendana, Kupang

\begin{abstract}
Abstrak
Era globalisasi dapat menimbulkan perubahan pola hidup masyarakat yang lebih modern. Akibatnya masyarakat cenderung untuk memilih kebudayaan baru yang dinilai lebih praktis dibandingkan dengan budaya lokal. Salah satu faktor yang menyebabkan budaya lokal dilupakan dimasa sekarang adalah; kurangnya generasi penerus yang memiliki minat untuk belajar dan mewarisi kebudayaannya sendiri.Oleh karena itu, penulisan artikel ini bertujuan untuk memaparkan tentang upaya melestarikan budaya Indoesia di era globalisasi.Metode yang digunakan dalam tulisan ini adalah kualitatif dengan teknik studi pustaka dalam mengumpulkan data. Menurut Malinowski, Budaya yang lebih tinggi dan aktif akan mempengaruhi budaya yang lebih rendah dan pasif melalui kontak budaya. Teori Malinowski ini sangat nampak dalam pergeseran nilainilai budaya kita yang condong ke Barat.Dalam era globalisasi informasi menjadi kekuatan yang sangat dahsyat dalam mempengaruhi pola pikir manusia.Untuk mengatasi hal ini, perlu kesadaran akan pentingnya budaya lokal sebagai jati diri bangsa. Kewajiban bagi setiap lapisan masyarakat untuk mempertahankannya, dimana peran generasi muda sangat diharapkan untuk terus berusaha mewarisi budaya lokal dan akan menjadi kekuatan bagi eksistensi budaya lokal itu sendiri walaupun diterpa arus globalisasi. Upaya dalam Menjaga dan melestarikan budaya Indonesia dapatdilakukan dengan dua cara. yaitu; Culture Experiencedan Culture Knowledge.
\end{abstract}

Kata Kunci: Melestarikan, budaya nasional, globalisasi.

\begin{abstract}
The era of globalization can lead to changes in the lifestyle of a more modern society. As a result, people tend to choose a new culture that is considered more practical and simpler than the local culture. One of the factors that cause local culture to be forgotten in the present is; lack of future generations who have an interest in learning
\end{abstract}


and inheriting their own culture. Therefore, this article aims to describe the efforts to maintain Indonesia culture in the era of globalization. According to Malinowski, higher and more active cultures will influence lower and passive cultures through culture contact. Malinowski's theory shows the shifting in our culture to Western-leaning cultural values. In the era of globalization, information is a very powerful force in influencing the human mindset. To cope with this, awareness of the importance of local culture is needed as a nation identity. It is an obligation for every layer of society to maintain it. Moreover, the role of the younger generation is expected the most to continue to try to inherit local culture and will be a force for the existence of local culture itself despite the current of globalization. Efforts to protect and preseve Indonesian culture can be done in two ways, they are; Culture Experience and Culture Knowledge.

Keywords: Preserving, national culture, globalization

\section{PENDAHULUAN}

Kebudayaan Indonesia adalah keseluruhan kebudayaan lokal yang ada disetiap daerah di Indonesia.Kebudayaan nasional dalam pandangan Ki Hajar Dewantara adalah “puncak-puncak dari kebudayaan daerah”.Kutipan pernyataan ini merujuk pada paham kesatuan makin dimantapkan, sehingga ketunggalikaan makin lebih dirasakan daripada kebhinekaan.Wujudnya berupa negara kesatuan, ekonomi nasional, hukum nasional, serta bahasa nasional.Kebudayaan Indonesia dari zaman ke zaman selalu mengalami perubahan, perubahan ini terjadi karena faktor masyarakat yang memang menginginkan perubahan dan perubahan kebudayaan terjadi sangat pesat yaitu karena masuknya unsur-unsur globalisasi ke dalam kebudayaan Indonesia. Unsur globalisasi masuk tak terkendali merasuki kebudayaan nasional yang merupakan jelmaan dari kebudayaan lokal yang ada disetiap daerah dari Sabang sampai Merauke ( Tobroni: 2012 : 123)

Pola hidup masyarakat masa kini dengan masa dahulu sangatlah berbeda hal ini juga dampak arus globalisasi sehingga perlu penanganan yang lebih baik. Dampaklain dari globalisasi yaitu berkembangnya teknologi-teknologi canggih yang sangat membantu manusia namun juga dapat merusak mental dan moral generasi muda. Sebagai contoh pada Masyarakat NTT yang dahulunya sangat menjunjung tinggi budaya gotong royong dalam menyelesaikan pekerjaan di bidang pertanian, namun pada saat ini masyarakat cenderung menggunakan mesin mulai dari menanam hingga proses penggilingan padi, sehingga budaya gotong royong yang sangat kental dalam masyarakat perlahan-lahan mulai dilupakan pada generasi muda dimana; solidaritas mekanik dan solidaritas organik. Sesuai dengan teori dari salah satu tokoh sosiologi 
yaitu Emile Durkheim berpendapat bahwa; dalam masyarakat ada dua jenis solidaritas yaitu solidaritas mekanik yang kebersamaannya berdasarkan rasa kekeluargaan sedangkan solidaritas organik kebersamaannya berdasarkan adanya kepentingan. Oleh karena itu semua unsur budaya dari luar yang masuk pada masa sekarang, perlu dikaji terlebih dahulu sebelum menerapkan unsur tersebut.

Dari sekian banyak kebudayaan yang terdapat di Indonesia mulai dari kuliner, fashion, kesenian, seperti ada kuliner dari beberapa daerah sebagai contoh; rendang dari Padang, kue delapan jam dari Palembang, sate susu dari pulau Dewata, gudeg dari Yogyakarta, jagung bose dari Timor, mempunyai ciri khas tersendiri. Semuanya merupakan aset bangsa yang perlu dijaga dan dilestarikan agar keaslian dan eksistensinya tidak dikikis oleh derasnya arus globalisasi. Adanya fenomena menarik di antara keberagaman budaya di setiap daerah Indonesia, menjadi alasan kuat bagi Penulis untuk membuat satu tulisan ilmiah dengan judul: Upaya melestarikan Budaya Indonesia di Era Globalisasi.

Melihat kenyataan bahwa masyarakat Indonesia saat ini lebih memilih kebudayaan asing yang mereka anggap lebih menarik ataupun lebih unik dan praktis. Kebudayaan lokal banyak yang luntur akibat dari kurangnya generasi penerus yang memiliki minat untuk belajar dan mewarisinya.Menurut Malinowski, Budaya yang lebih tinggi dan aktif akan mempengaruhi budaya yang lebih rendah dan pasif melalui kontak budaya (Malinowski dalam Mulyana, 2005:21). Teori Malinowski ini sangat nampak dalam pergeseran nilai-nilai budaya kita yang condong ke Barat.

Dalam era globalisasi informasi menjadi kekuatan yang sangat dahsyat dalam mempengaruhi pola pikir manusia.Budaya barat saat ini diidentikkan dengan modernitas (modernisasi), dan budaya timur diidentikkan dengan tradisional atau konvensional. Orang tidak saja mengadopsi ilmu pengetahuan dan teknologi Barat sebagai bagian dari kebudayaan tetapi juga meniru semua gaya orang Barat, sampai-sampai yang di Barat dianggap sebagai budaya yang tidak baik tetapi setelah sampai di Timur diadopsi secara membabi buta. Seorang yang sudah lama menetap di Australia kemudian mudik ke Indonesia, ia tercengang melihat betapa cepatnya perubahan budaya di Indonesia. Ia saat itu bahkan merasa berada di Amerika. Ada beberapa saluran TV yang menayangkan banyak film Amerika yang penuh dengan adegan kekerasan dan seks. Selama beberapa minggu ia berada di tanah air, ia tidak melihat kesenian tradisional 
yang ditayangkan di TV swasta seperti yang pernah dilihatnya dahulu di TVRI. Ia kemudian sadar bahwa reog, angklung, calung, wayang golek, gamelan, dan tarian tradisional tidak hanya nyaris tidak ditayangkan di TV, tetapi juga jarang sekali dipertontonkan langsung di tengah-tengah masyarakatnya. Sementara itu, ia justru menemukan Mc. Donald's, Kentucky Fried Chicken, Pizza Hut, dan Dunkin Donuts di sini. Beberapa toserba dan pasar swalayan juga mirip seperti yang ia temukan di luar negeri dengan penataan yang serupa. Kedua tempat berbelanja tersebut bahkan lebih banyak menggunakan petunjuk-petunjuk berbahasa Inggris, meskipun mayoritas pengunjungnya adalah orang Melayu.Ia melihat banyak pemuda bergaya masa kini, dengan rambut panjang sepertiekor kuda, sebelah telinganya beranting, bercelana Levi's duduk-duduk santai di Mall, seraya meneguk minuman dingin 'Soft Drink'. Demikian pula pemuda-pemudinya banyak sekali yang hanya menggunakan kaos sepotong yang ketat dan tidak sempat menutup pusarnya, dengan celana panjang yang ketat pula, sedangkan rambutnya disisir dengan gaya semrawut.

Di kota-kota besar sudah tumbuh pub-pub, night-club, diskotik dan karaoke yang sangat laris. Restoran-restoran yang menyediakan makanan ala China, dan Eropa. Ia tertegun benarkah ini negeriku Indonesia? Fenomena tersebut menunjukkan bahwa kebudayaan Indonesia yang halus dan yang tinggi nilai budayanya telah terkontaminasi oleh kebudayaan Barat yang sekuler seperti itu? Karenanya, kewajiban bagi setiap lapisan masyarakat untuk mempertahankan kebudayaan yang dimiliki sejak dahulu dan diwariskan secara turun-temurun.Peran generasi muda sangat diharapkan untuk terus berusaha belajar dan dapat mewarisinya. Oleh karena itu, dalam tulisan ini penulis bertujuan ingin memaparkan tentang: 1) Pengertian Kebudayaan, 2) Perkembangan kebudayaan di Indonesia 3) Pembelajaran tentang Budaya Lokal 4) Upaya-upaya dalam Melestarikan Budaya Indonesia.

\section{METODE PENELITIAN}

Metode yang digunakan adalah kualitatif dengan teknik pengumpulan datanya studi pustaka, dimana penulis menelaah beberapa sumber pustaka sebagai referensi dalam penulisan ini. 


\section{PEMBAHASAN}

\section{Pengertian Kebudayaan}

Menurut Koentjaraningrat (2015: 146) kebudayaan diartikan sebagai keseluruhan gagasan dan karya manusia yang harus dibiasakannya dengan belajar, beserta keseluruhan dari hasil budi dan karyanya itu. Bila dilihat dari bahasa inggris kata kebudayaan berasal darikata latincolera yang berarti mengolah atau mengerjakan, yang kemudian berkembang menjadi kata culture yang diartikan sebagai daya dan usaha manusia untuk merubah alam.Banyak berbagai definisi dari kebudayaan, namun terlepas dari itu semua kebudayaan pada hekekatnya mempunyai jiwa yang akan terus hidup, karena kebudayaan terus mengalir pada diri manusia dalam kehidupannya. Kebudayaan akan terus tercipta, dari tempat ketempat, dari individu ke individu dan dari masa ke masa. Berdasarkan pendapat Koentjaraningrat diatas menggambarkan bahwa kebudayaan selalu akan mengalami perubahan-perubahan dari waktu ke waktu sehingga masyarakat yang memiliki kebudayaan itu harus tetap mengenal, memelihara dan melestarikan kebudayaan yang dimiliki agar setiap perubahan yang terjadi tidak menghilangkan karakter asli dari kebudayaan itu sendiri.

\section{Perkembangan Kebudayaan di Indonesia}

Kebudayaan dan masyarakat adalah ibarat dua sisi mata uang, satu sama lain tidakdapat dipisahkan.Disamping itu, Indonesia merupakan negara yang kaya akan berbagai macam budaya sosial masyarakat yang unik dan indah serta sangat cocok bagi para pelancong yang ingin melihat pesona sosial budaya Indonesia. Oleh karena itu, para wisatawan sangat antusias untuk memenuhi kerinduannya dalam menyaksikan langsung akanNatural Wonderful cultureyang sulit ditemui pada bagian bumi yang lain di dunia ini. Pada tahun 2018, semua orang dari semua penjuru di dunia berbondongbondong datang ke Labuanbajo NTT, hanya untuk mau menyaksikan langsung kebudayaan lokal dan komodo-komodo yang ada disana.

Teori Sinkronisasi Budaya (Hamelink dalam Liliweri, 1983: 23) menyatakan "lalu lintas produk budaya masih berjalan satu arah dan pada dasarnya mempunyai mode yang sinkronik. Negara-negara Metropolis terutama Amerika Serikat menawarkan suatu model yang diikuti negara-negara satelit yang membuat seluruh proses budaya lokal menjadi kacau atau bahkan menghadapi jurang kepunahan. Dimensi-dimensi yang unik dari budaya Nusantara dalam spektrum nilai kemanusiaan yang telah berevolusi 
berabad-abad secara cepat tergulung oleh budaya mancanegara yang tidak jelas manfaatnya.Ironisnya hal tersebut justru terjadi ketika teknologi komunikasi telah mencapai tataran yang tinggi, sehingga kita mudah melakukan pertukaran budaya. (Dalam sumber yang sama) Hamelink juga menyatakan, bahwa dalam sejarah budaya manusia belum pernah terjadi lalu lintas satu arah dalam suatu konfrontasi budaya seperti yang kita alami saat ini. Karena sebenarnya konfrontasi budaya dua arah di mana budaya yang satu dengan budaya yang lainnya saling pengaruh mempengaruhi akan menghasilkan budaya yang lebih kaya (kompilasi). Sedangkan konfrontasi budaya searah akan memusnahkan budaya yang pasif dan lebih lemah. Menurut Hamelink, bila otonomi budaya didefinisikan sebagai kapasitas masyarakat untuk memutuskan alokasi sumber-sumber dayanya sendiri demi suatu penyesuaian diri yang memadai terhadap lingkungan, maka sinkronisasi budaya tersebut jelas merupakan ancaman bagi otonomi budaya masyarakatnya. Hal ini terjadi pada masyarakat Indonesia dimana, jaman sekarang masyarakat lebih suka merayakan Ulang tahun di tempat-tempat yang identik dengan budaya Barat sehingga dinilai tidak kuno lebih modern. Misalnya; KFC,Dunkin Donuts Pizza Hut.

Pada awalnya, Indonesia mempunyai banyak peninggalan budaya dari nenek moyang kita terdahulu, hal seperti itulah yang harus dibanggakan oleh penduduk Indonesia sendiri, tetapi saat ini budaya Indonesia sedikit menurun dari sosialisasi di tingkat nasional,sehingga masyarakat kini banyak yang melupakan dan tidak mengetahui apa itu budaya Indonesia. Semakin majunya arus globalisasi rasa cinta terhadap budaya semakin berkurang, dan hal ini sangat berpengaruh terhadap keberadaan budaya lokal dan bagi masyarakat asli Indonesia.

Saat ini Indonesia lebih gencar mempromosikan budaya Indonesia dalam kancah Internasional, buktinya masyarakat luar lebih mengenal budaya Indonesia dibandingkan masyarakat Indonesia.Sebagai contoh adalah batik hasil dari budaya Indonesia, batik tersebut belakangan ini termasuk salah satu budaya yang diminati oleh masyarakat luar.Muncul trend ini dikarenakan batik telah ditetapkan oleh UNESCO pada hari jumat tanggal 02 oktober 2009 sebagai warisan budaya Indonesia, dan hari itulah ditetapkannya sebagai hari batik nasional.

Ada sejumlah kekuatan yang mendorong terjadinya perkembangan sosial budaya masyarakat Indonesia.Secara kategorikal ada 2 kekuatan yang menyebabkan terjadinya 
perubahan sosial, Petama, adalah kekuatan dari dalam masyarakat sendiri (internal factor), seperti pergantian generasi dan berbagai penemuan dan modifikasi setempat. Kedua, adalah kekuatan dari luar masyarakat(external factor), seperti pengaruh kontakkontak antar budaya (culture contact) secara langsung maupun persebaran (unsur) kebudayaan serta perubahan lingkungan hidup yang pada gilirannya dapat memacu perkembangan sosial dan kebudayaan masyarakat yang harus menata kembali kehidupan mereka ( Koentjaraningrat, 2015: 191).

\section{Pembelajaran tentang Budaya Lokal}

Kesadaran masyarakat untuk menjaga budaya lokal sekarang ini terbilang masih sangat minim.Masyarakat lebih memilih budaya asing yang lebih praktis dan sesuaidengan perkembangan zaman.Hal ini bukan berarti bahwa tidak boleh mengadopsi budaya asing, namun banyak budaya asing yang tidak sesuai dengan kepribadian bangsa. Seperti masuknya budaya asing yaitu budaya berpakaian yang lebih mini dan terbuka yang sering dikenal istilah" you can see" dimana tidak sesuai dengan budaya Indonesia yang menganut nilai sopan santun dan ditunjang dengan mayoritas penduduknya beragama islam yag menjunjung tinggi cara berpakaian yang dapat menutup aurat. Budaya lokal juga dapat disesuaikan dengan perkembangan zaman, selagi tidak meninggalkan ciri khas dari budaya aslinya. Kurangnya pembelajaran budaya merupakan salah satu sebab dari memudarnya budaya lokal bagi generasi muda. Oleh karena itu, Pembelajaran tentang budaya, harus ditanamkan sejak dini. Namun sekarang ini banyak yang sudah tidak menganggap penting mempelajari budaya lokal. Hal ini dibuktikan dengan dalam setiap rencana pembangunan pemerintah, bidang sosial budaya masih mendapat porsi yang sangat minim. Padahal melalui pembelajaran budaya, kita dapat mengetahui pentingnya budaya lokal dalam membangun budaya bangsa serta bagaiman cara mengadaptasikan budaya lokal di tengah perkembangan zaman yaitu era globalisasi (Sedyawati: 2006: 28).

\section{Upaya-upaya dalam Melestarikan Budaya Indonesia}

Pelestarian sebagai kegiatan atau yang dilakukan secara terus menerus, terarah dan terpadu guna mewujudkan tujuan tertentu yang mencerminkan adanya sesuatu yang tetap dan abadi, bersifat dinamis, luwes, dan selektif.Pelestarian budaya adalah upaya untuk mempertahankan nilai-nilai seni budaya, nilai tradisional dengan mengembangkan perwujudan yang bersifat dinamis, luwes dan selektif, serta 
menyesuaikan dengan situasi dan kondisi yang selalu berubah dan berkembang.Widjaja (1986) mengartikan pelestarian sebagai kegiatan atau yang dilakukan secara terus menerus, terarah dan terpadu guna mewujudkan tujuan tertentu yang mencerminkan adanya sesuatu yang tetap dan abadi, bersifat dinamis, luwes dan selektif (Widjaja dalam Ranjabar, 2006:56).

Menjaga dan melestarikan budaya Indonesia dapatdilakukan dengan berbagai cara. Ada dua cara yang dapat dilakukan masyarakat khususnya sebagai generasi muda dalam mendukung kelestarian budaya dan ikut menjaga budaya lokal (Sendjaja, 1994: 286). yaitu :

\section{Culture Experience}

Culture Experience Merupakan pelestarian budaya yang dilakukan dengan cara terjun langsung kedalam sebuah pengalaman kultural. contohnya, jika kebudayaan tersebutberbentuk tarian, maka masyarakat dianjurkan untuk belajar dan berlatih dalam menguasai tarian tersebut, dan dapat dipentaskan setiap tahun dalam acara-acara tertentu atau diadakannya festival-festival. Dengan demikian kebudayaan lokal selalu dapat dijaga kelestariannya.

\section{Culture Knowledge}

Culture Knowledge Merupakan pelestarian budaya yang dilakukan dengan cara membuat suatu pusat informasi mengenai kebudayaan yang dapat difungsionalisasi ke dalam banyak bentuk. Tujuannya adalah untuk edukasi ataupun untuk kepentingan pengembangan kebudayaan itu sendiri dan potensi kepariwisataan daerah.Dengan demikian para Generasi Muda dapat memperkaya pengetahuannya tentang kebudayaanya sendiri. Selain dilestarikan dalam dua bentuk diatas, kebudayaan lokal juga dapat dilestarikan dengan cara mengenal budaya itu sendiri. Dengan demikian, setidaknya dapat diantisipasi pembajakan kebudayaan yang dilakukan oleh negaranegara lain. Persoalan yang sering terjadi dalam masyarakaat adalah terkadang tidak merasa bangga terhadap produk atau kebudayaannya sendiri. Kita lebih bangga terhadap budaya-budaya impor yang sebenarnya tidak sesuai dengan kepribadian bangsa sebagai orang Timur. Budaya lokal mulai hilang dikikis zaman, Oleh sebab masyarakat khususnya generasi muda yang kurang memiliki kesadaran untuk melestarikannya. Akibatnya kita baru bersuara ketika negara lain sukses dan terkenal, dengan budaya yang mereka ambil secara diam-diam. Oleh karaena itu peran pemerintah dalam 
melestarikan budaya bangsa juga sangatlah penting. Bagaimanapun juga pemerintah memiliki peran yang sangat besar dalam upaya pelestarian kebudayaan lokal di tanah air.

Pemerintah harus mengimplementasikan kebijakan-kebijakan yang mengarah pada upaya pelestarian kebudayaan nasional. Salah satu kebijakan pemerintah yang pantas didukung adalah penampilan kebudayaan-kebudayaan daerah disetiap eventevent akbar nasional, misalnya tari-tarian, lagu daerah dan pertunjukkan sarung ikat dan sebagainya. Lebih konkrit lagi pada akhir-akhir ini Presiden Joko Widodo mewajibkan semua jajarannya agar setiap event penting nasional seperti pada HUT RI tanggal 17 Agsutus setiap tahun mengenakan pakaian tradisional masing-masing berdasarkan daerah asalnya. Hal ini perlu diapresiasi karena merupakan salah satu upaya dalam melestarikan budaya Indonesia . Semua itu dilakukan sebagai upaya pengenalan kebudayaan lokal kepada generasi muda, bahwa budaya yang ditampilkan itu adalah warisan dari leluhurnya,bukan berasal dari negara tetangga, demikian juga upaya-upaya melalui jalur formal pendidikan ( Ranjabar : 2006: 34).

Masyarakat wajib memahami dan mengetahui berbagai macam kebudayaan yang dimiliki.Pemerintah juga dapat lebih memusatkan perhatian pada pendidikan muatan lokal kebudayaan daerah.Selain hal-hal tersebut diatas, masih ada cara lain dalam melestarikan budaya lokal ( Yunus: 2014: 123) yaitu:

a. Meningkatkan kualitas sumber daya manusia dalam memajukan budaya lokal.

b. Mendorong masyarakat untuk memaksimalkan potensi budaya lokal beserta pemberdayaan danpelestariannya.

c. Berusaha menghidupkan kembali semangat toleransi, kekeluargaan, keramahtamahan dan solidaritas yang tinggi.

d. Selalu mempertahankan budaya Indonesia agar tidak punah. Mengusahakan agar masyarakat mampu mengelola keanekaragaman budaya lokal.

Kebudayaan Indonesia adalah kebudayaanyang ada hanya dimiliki oleh bangsa Indonesia dan setiapkebudayaan daerah mempunyai ciri khas masing-masing.Bangsa Indonesia juga mempunyai kebudayaan lokalyang sangat kaya dan beraneka ragam. Oleh sebab itu, sebagai generasi penerus, kita wajib menjaganya karena eksistensi dan ketahanankebudayaan lokal berada pada generasi mudanya, dan 
jangan sampai kita terbuai apalagi terjerumus pada budayaasing karena tidak semua budayaasing sesuai dengan kepribadian bangsa Indonesia bahkan banyak kebudayaan asing membawa dampak negatif. Sebagai negara kepulauan pasti sulit untuk mempertahankan persatuan dan kesatuan antara masyarakat.Namun, hal itu bisa diminimalisir jika kita memiliki kepedulian dan kesadaran untuk menjaga, mempelajari, serta melestarikan, sehinggakebudayaan lokal yang sangat kaya di Indonesia ini tetap utuh dan tidak punah apalagi sampai dibajak ataudicuri oleh negara lain karena kebudayaan merupakan identitas suatu bangsa dan negara.

\section{KESIMPULAN}

Indonesia merupakan negara yang mempunyai banyak sekali kebudayaan, yang terdiri dari kumpulan kebudayaan yang ada di seluruh tanah air Indoesia yang berbentuk kebudayaan lokal. Budaya asing terus masuk dengan tidakterbendung ke Indonesia yang dapat mengikis ataupun melunturkan budaya lokal yang dimiliki oleh bangsa Indonesia, untuk ituperlunya upaya-upaya penting terus dilakukan dalam menanggulangi permasalahan tersebut sehingga budaya Indonesia dapat tetap eksis dalam keasliannya walaupun diterpa arus globalisasi. Berbagai cara dapat dilakukan dalam melestarikan budaya, namun yang palingpenting yang harus pertama dimiliki adalah menumbuhkan kesadaran serta rasa memiliki akan budaya tersebut, sehingga dengan rasa memiliki serta mencintai budaya sendiri, orang akan termotivasi untuk mempelajarinya sehingga budaya akan tetap ada karena pewaris kebudayaannya akan tetap terus ada. Ada berbagai upaya yang dapat dilakukan untuk melestarikan budaya lokal diantaranya:

1. Menumbuhkan kesadaran tentang pentingnya budaya sebagai jati diri bangsa.

2. Ikut melestarikan budaya dengan cara berpartisipasi dalam pelestarian dan pelaksanaannya.

3. Mempelajarinya dan ikut Mensosialisasikan kepada orang lain sehingga mereka tertarik untuk ikut menjaga atau melestarikannya bahkan mempertahankannya.

Budaya lokal merupakan aset Bangsa Indonesia yang harus memperoleh perhatian terutama di era Globalisasi saat ini.Budaya nasional menjadi bagian penting negara Indonesia yang dapat dikembangkan dan dikelola sebaik-baiknya.Hal ini penting agar dapat berfungsi lebih luas tidak hanya sekadar warisan ataupun adat istiadat masyarakat Indonesia yang dirayakan ataupun dilaksanakan pada saat peringatan hari 
Sumpah Pemuda atau hari Pahlawan saja. Budaya nasional harus menjadi bagian dari aset Bangsa Indonesia yang dapat mendatangkan pendapatan bagi masyarakat dan negara.Tentunya perlu ada suatu kesadaran secara nasional dan dilaksanakan oleh seluruh masyarakat Indonesia pada semua aspek kehidupan bermasyarakat dan bernegara.

\section{DAFTAR PUSTAKA}

Liliweri. Alo, 2007, Makna Budaya dalam Komunikasi Antar Budaya, Yogyakarta, LkiS.

Koendjaraningrat,Pengantar Ilmu Antropologi, Sejarah Teori Antropologi, Jakarta, Rineka Cipta, 2015.

Mulyana, Deddy, 2005, Ilmu Komunikasi Suatu Pengantar, Bandung, Remaja Rosdakarya

Ranjabar. Jacobus, 2006, Sistem Sosial Budaya Indonesia, Suatu Pengatar, Bandung, Ghalia Indonesia.

Sendjaja, S. Djuarsa, 1994, Teori Komunikasi, Jakarta, Universitas Terbuka

Sedyawati, Edi. 2006. Budaya Indonesia: Kajian Arkeologi, Seni, dan Sejarah. Jakarta: Raja Grafindo Persada

Soekanto, Soerjono, Sosiologi Suatu Pengantar, Jakarta, Raja Grafindo Persada, 2003.

Tobroni.2012. Relasi Kemanusiaan dalam Keberagaman (Mengembangkan Etika Sosial Melalui Pendidikan). Bandung: Karya Putra Darwati.

Yunus. Rasid, 2014, Nilai-Nilai Kearifan Lokal (Local Genius) Sebagai Penguat Karakter Bangsa, Studi Empiris Tentang Hayula, Yogyakarta, Budi Utama.

http://iindramawan.blogspot.com/2013/03/upaya-melestarikan-budayabangsa.html http://lorentfebrian.wordpress.com/perkembangan-budaya-di-indonesia/ https://www.academia.edu/5448812/Melestarikan_Budaya_Lokal_sebagai_Aset_Kekay a an_Nasional http://www.academia.edu/3721187/makalah_isbd_kebudayaan

https://media.neliti.com/media/publications/243158-none-98ba8711.doc, Tantangan Pelestarian Budaya Nasional di Era Globalisasi. 
76IHildigardis M.I. Nahak

Upaya Melestarikan BudayaIndonesiaDi Era Globalisasi

Dikutip dari artikel bertajuk Pemertahanan Nilai-Nilai Budaya Lokal dalam Pembelajaran Sastra di Sekolah, diakses melalui http://badanbahasa.kemdikbud.go.id/lamanbahasa/artikel 